\title{
Cultural Reconciliation and Music: Musical Dialogues Direction to Reconciliation between Turkish and Greek Communities in Cyprus
}

\author{
By Umut Albayrak*
}

This study has been done to understand the role of music in inter-community reconciliation and to examine music as a cultural solution area between Turkish and Greek communities in Cyprus. The main focus of the study is on musical dialogues towards the reconciliation between Turkish Cypriot and Greek Cypriot communities. Accordingly it touches upon the contributions of music to the reconciliation between two communities and how it is being used to create a mutual identity. Therefore, bicommunal gatherings, sense of entertainment, songs as a method of a self-expression, and instrument sessions of two communities have been reviewed in the contribution of music in the reconciliation. Although people are still researching whether music can be effective in inter-community reconciliations or not, the role it plays in reconciliations and conflict has been discussed with examples. The view of music creating conflict and reconciliation between communities has been examined under the concepts such as cultural reconciliation, cultural identity, the pragmatic use of music and multiculturalism.

Keywords: Cultural Identity, Cultural Reconciliation, Cyprus Music, Greek Cypriot, Turkish Cypriot.

\section{Introduction}

This study aims to gain an understanding of the role of music in reconciliation between communities and evaluate music as a cultural area of resolution between the Turkish and Greek communities in Cyprus. It focuses on musical dialogues toward reconciliation between Turkish and Greek Cypriot communities. The study hypothesizes that political boundaries are influential only to a certain level in determining cultural boundaries, and these political boundaries are crossed either legally or illegally, thus falling short of completely preventing the shaping of culture and cultural behavior. The study has been shaped with data collection, which includes fieldwork based observation and interview techniques and also literature research on cultural and social reconciliation. As a Turkish Cypriot, I have examined this study from the inside with the identity and culture of which I am part, and also from the outside with my researcher identity to make an independent and impartial evaluation. Though the rare studies on Cyprus in the literature present a challenge, being a researcher from this identity and culture has helped to decide the practice in addition to the theory. The fact that I am not a member of any of the musical organizations studied has allowed me to interpret the results from an unbiased point of view.

\footnotetext{
* Dr., Eastern Mediterranean University, Cyprus.
} 
This study sets forth the idea that music has the power to create reconciliation and conflict between cultures and communities, through concepts such as cultural reconciliation, cultural identity, pragmatic use of music and multiculturalism. The topic is discussed through examples of the use of music for conflict and reconciliation and the implemented musical dialogues. In the other part of the study, the concepts related to the musical dialogues, places, initiatives and organizations created by Turkish and Greek Cypriot communities in order to create an area of reconciliation are associated with related concepts.

\section{Cultural Reconciliation and Musical Dialogue}

\section{Cultural Reconciliation}

Reconciliation is the ability to meet at a common point regarding disputes and to reach an agreement on these disputes. At the same time it can build mutual trust, which is one of the requirements of peace. There are different approaches on the steps that need to be taken in achieving the reconciliation process. In the liberal approach, an urgent political and economical cooperation between the sides gains importance, whereas in the social psychological approach the cognitive and emotional aspects of reconciliation are highlighted. In order to achieve reconciliation following a national or international conflict and to ensure steady peace, all the segments of society must be involved in the process, and the points that create the conflict must be correctly identified and discussed. Throughout history, the impact of reconciliation in the stabilization of peace relations has been proven with Germany - France, Germany - Poland and Germany - Czech Republic relations (Bar-Siman-Tov 2004: 3-4-5).

The communities that have problems with each other need to communicate and start a dialogue to solve these problems. "Cultural reconciliation" is an important step for communities to come closer and create common spaces. One of its most important actors is music. Music facilitates reaching larger audiences, and it can be used to express and support their conflicts and rebellion in accordance with their beliefs, as well as to create reconciliation on the path to resolution. The power of music to enable conflict or reconciliation between communities stems from its use as a social behavior. The pragmatic use of music takes place at this point. Using music to provide benefits for a specific purpose is using it pragmatically and showcases what music can do (Keammer 1993: 67). The meanings attributed to music push people to struggle; the ideological and political use of music is related to this. Hall defines ideology as "the complete concepts and structures that form the framework which we utilize to make sense of, figure out and represent specific aspects of our social existence" (Larrain 1995: 106). Music takes two forms when associated with ideology: music policies that the governing powers implement in line with their ideology, and musical behavior that reveals and is shaped by people's attitude towards these policies. When the purpose is to create conflict or aggravate differences, music can play a functional role. The music that is identified with the advocated 
ideology or the affiliated community highlights "We" against "Others" and naturally creates discrimination.

"Music is an element of expression that historically accompanies political events, sometimes shaping them and at other times guiding them, and has often been used as a tool for probing history" (Erol 2005: 185).

Cultural identity highlights the differences between communities and also reveals partnership. It is also effective in maintaining differences between cultures; and it can also be defined as a new identity, which is a combination of the respective cultural identities of both cultures. This is where multiculturalism emerges. Multicultural societies encompass multiple cultures, and thus the common culture come into existence as part of the interaction within this cultural diversity and the respect that different groups give to each other. Thus, it can gather individuals under a common lifestyle (Parekh 2002: 280).

"The shared culture that is constructed multiculturally creates a common feeling of belonging among citizens, establishing a common language and an overlapping set of values that originate from and nourished by the dialogue between them" (Parekh 2002: 286).

Culture brings communities together, enabling them to get to know each other, respect each other and have dialogues that will build an environment of trust. It is not possible to talk about a social unity where culture is not included. It impacts directly the relation of people through conflicts and reconciliation. It provides solutions in order to overcome conflicts. Cultural events, products and heritage are the main terms in reconciliation dialogues and play key roles. It actively aids the stopping of violence in conflict situations (Preis and Mustea 2013: 2-5).

Reconciliation requires dialogue. Dialogue begins when two different sides of an issue start discussing a point, which requires interaction and reciprocal communication. Musical behavior, organizations and social requests that provide reciprocal communication are dialogues toward creating reconciliation. Dialogue, a linguistic phenomenon, defines the cultural area. Artists of communities that have problems engage in dialogues with other artists and enter into a search for a solution in the cultural and political area through art. This makes art in general, and music in particular, which is the focus of the study, an important tool in the dialogue process. They aim to create an environment of reconciliation by meeting on a cultural common ground other than their primary cultural identities, such as "Cypriot", "Islander" or "Mediterranean". The objective here is to establish a ground for the desired reconciliation by creating spots of common culture.

A link can be established between reconciliation and the past with the aid of music. Music is able to give more effective results in the recognition and promotion of societies than historical facts because music carries traces, influences and meanings related to the cultures and histories of societies (Gray 
2015: 64). Laurence suggests that "music, along with all its other functions and effects, indeed offers a specific potential to enable, catalyze and strengthen empathic response, ability and relationship, and that it is this potential capacity which lies at the core of music's function within peace building" (Laurence 2015: 14). Cohen also states that music is suitable for peace building because it helps in the establishment of empathy and makes it easier to communicate (Cohen 2015, cited by Gray 2015: 76). Music can play a crucial role in reconciliation, through the recognition of each other, the redefinition of identities, and the emergence of sympathies between parties (Garcia 2014: 28).

\section{The Conflicting Aspect of Music}

The use of music in creating environments of conflict and reconciliation is ideological. Music is shaped by that political ideology and becomes a method of struggle for a particular group. It mobilizes the community, it creates agitation, and it emphasizes propagandas. That is, music is used to provide benefits that will work. "In its pragmatic use, music is constructed as part of the practical results that are expected from it. The basic motivating aspect of music is the practical benefit" (İyit 2008: 26). Use of music as a tool for propaganda and in an agitating way is particularly associated with the ideological struggles of the twentieth century. With the agitating aspect, the aim is to bring about a specific political reflex in the audience. The music takes on the form of propaganda with its relation to its function, place of use and the activities with which it is associated (Clark 2004: 20). According to Edgar and Sedgwick, propaganda is the effort to control the behavior or attitude of a group by deliberately providing information, manipulating communication and using visual materials (2007: 293). "Popular music is predominantly pragmatic because it gives people the opportunity to produce meanings of their own. Dependent social layers give a "resistance" structure to the popular music in opposition to the political power, to the extent that they are able to produce their own meanings when building their cultural identities" (İyit 2008: 26).

Music is not only used to resist against the ruling powers. It is also used by the ruling powers as a guide to make desired effects on the societies, and it is designed to influence society's consciousness. By this means it aids the building of pro-government structures while weakening the opposition's criticism and resistance. One of the most important examples of this in history is Nazi Germany, where music was used to neutralize resistance between populations (Selçuk, 2016: 6). Ruling powers use popular culture products to numb the societies and make them act within the ideological boundaries (Selçuk 2016: 28).

Music is constantly used as a center of meetings in rallies, as an instrument of torture to the enemy during wars, to spread unity and courage to allies, to spread ideologies in daily life and to create national identity (Berg and Sloboda 2010: 4-5). 


\section{The Conciliatory Aspect of Music}

Even though music is not sufficient on its own to resolve political issues, it is influential in drawing attention to the issue and injecting the society with an awareness regarding conflict resolution. As artists start to act together for reconciliation, communities and cultures cease being "We" and "Others" and become associated with "All of us" as part of the shared geography. Differences and their own respective cultures do not disappear as a result of this reconciliation. The stage represents the space where the reconciliation takes place.

Artists have come together and used the stage as a space of reconciliation. During this effort, in addition to traditional music styles, they have gathered various music genres, different languages, and artists from different musical backgrounds to draw the attention of the global community. For example, the Israeli musician Yair Dalal, who has taken important steps in the cultural communication of Israeli and Palestinian communities, has adopted the idea of the fusion of traditions. He has combined traditions from the Middle East to India and has created multicultural new tunes by incorporating the instruments and melodies of different traditions into his music (AI-Taee 2002: 53). He performed his song "Zaman el Salam" (Time for Peace) with a childrens' choir consisting of Israeli and Palestinian children in the event where Israelis and Palestinians celebrated the Peace Agreement in Oslo. According to Al Taee, the song was written in Arabic and Hebrew to express unity, harmonic existence and equality. The song blends Arabic and Israeli traditions in order to showcase its message (2002:53-54). Dalal ascribes a conciliatory role to his music in his albums and concerts. The artist, who produces collaborative work by combining the products of different cultures, regards differences as a cultural wealth and takes intercultural reconciliation to the stage.

In another example, Cheb Khaled, an important figure in Rai, together with Israeli singer Noa, pointed out the ongoing conflict between Arabs and Israelis through John Lennon's song "Imagine". They did a musical synthesis of east and west. While giving messages about coexistence in the song, it is also an important point that they sing the song in their own languages and also in each other's language (Al-Taee 2002: 56). In such works, it is important to demonstrate the value of peace and that communities can cooperate in harmony and give strong and significant messages. Thus, musical behavior takes shape to support this integrity. By blending this message with a world-renowned song, the artists took an important step toward creating a memorable and easily understandable message, which enabled the message to be effective by reaching a wide audience.

"Popular music acts as a field of negotiation and discussion and plays an important role in establishing unity in multicultural societies" (Lipsitz 1994: 126, cited by Al-Taee, 2002: 57).

"Music brings people together and enable them to better understand each other despite political differences. For this purpose, it not only reflects our understanding and vision of history, it also makes us appreciate the value 
of today, it clears ambiguities and paves the way for a better future" (AlTaee 2002: 59).

During the events organized in memory of the Holocaust and Kristallnacht, music performed has made concrete contributions to the resumption of cooperation and communication between societies. According to Goodwin, due to the cooperation between Jewish and German artists, there was a rise in performance and recording of the works of composers who were banned by the Nazis. With new works aimed at remembering war victims, the goal was to reconcile people and raise awareness among the young population. The music performed at the events assumed a role in creating reconciliation through collaborative works that signified the Jewish taking back their place in the German people's life as musicians, composers, dancers and viewers (2007:156).

Another example that uses music to create reconciliation is the work created to support the fall of the Berlin Wall. In 1987, as part of Berlin's 750thanniversary celebrations, music was used as an important tool in nourishing the idea of removing the barriers that physically, politically, socially, and culturally divided East and West Berlin. At the concert, Jeunesses Musicales International (JMI) performed Benjamin Britten's "War Requiem" to an audience of East and West Germans. This concert served as a cultural bridge between the two sides of the Berlin Wall. When the structure of JMI on the stage is examined, it can be seen that the orchestra itself was a symbol of reconciliation. The orchestra consisted of a young population from different nations, which saw music as a social regulatory force while instilling young musicians with the awareness that the musician must serve humanity through art and that they have responsibilities to the society. The place where the concert was organized, the performed work, the orchestra being composed of young people from different nationalities and the role of symbol for reconciliation, assumed by English and German soloists participating in the event, were deliberately arranged to use the stage for cultural reconciliation. With this broadcast made at this night, East and West Berlin made its first joint television broadcasting. With this broadcast reaching the world, an international testimony was provided for the moment of Berlin's unification through music. This attracted the attention of the world press and thus the concert had a huge resonance in the world (Goodwin 2007: 159-160).

Artists want to contribute to lasting peace through music. With political instability and in an environment of diminished hopes for the future, these initiatives by the artists once more strengthen the weakening belief for reconciliation and peace and encourage people to contribute in the process. Even though music cannot resolve the issue on its own, it creates awareness regarding social and political tensions. It provides tools to understand the changing dynamics in problematic structures, enables communication between the masses, and assumes an important role in instilling hope. The resulting attitude and behaviors may be the starting point of more comprehensive steps toward peace. Here, music indirectly takes its place as an element of the peace process. Even if the music does not form a diplomatic basis for official 
international contracts, it has a suitable structure that can start a cooperation for the resolution of problems.

\section{The "Mediator" Role of the Musician in Cultural Reconciliation}

Music is used by societies in order to provide an environment of reconciliation, and also emerges as the space of reconciliation in itself. In order for the music to function within the concept of cultural reconciliation, a decision should be made regarding how it will contribute to the solution of the problem. The aim may be to raise awareness in people, to emphasize common characteristics, or to build an awareness of collective work. Music should be processed and rendered beneficially, according to the purpose of use. At this point, the role of the musician is crucial because it is the musician who shapes the music. Musicians use music to create an atmosphere of reconciliation and try to tell people about the problem and its solution in effective ways that will appeal to their emotions. Artists have the option of lighting the way for society and sharing their beliefs with the world through their work. They feel responsible to the public. They have an important place in introducing cultures to new communities or into the new generations in their own community, thus ensuring their continuity. For example, songs and folk dance music identified with the cultural identity of "Cypriot" and embraced by the Turkish and Greek Cypriot communities, have taken their current form due to musicians' taking the role of mediator and carrying culture from one place to another. In the past, during the weddings in Cyprus that lasted for days, the musician spent time in different villages and towns and acquired new techniques, music and behavior patterns from each region. They contributed to the common culture of the island and enabled its continuity by sharing what they learned with the community in the new places they traveled. This is a confirmation of musicians' roles as mediators of culture. This is how, today, many popular anonymous pieces of Cypriot culture have taken their place in the repertoire. Turkish and Greek Cypriot musicians working together in Turkish and Greek weddings are one of the most important reasons why the behavior patterns between the two communities are intertwined. This collaborative work has also led to the formation of a common repertoire, as well as Turkish and Greek Cypriots learning both Turkish and Greek songs.

\section{The Tavern as a Space for Expressing Cultural Identity around Difference and Reconciliation}

\section{Cultural Identity and Space}

Cultural identity gives important clues in revealing similarities and differences between communities. The communities, which frequently express their cultural identity, assert their differences by distinguishing themselves from "Others". Spaces are living areas that are shaped by knowledge stored in memory, and they host traditions, habits, and knowledge of the society. Spaces 
are mediators that transfer social and cultural identity between times (Asiliskender 2004: 1). Their design and way of usage contain data regarding the identity and cultures of societies. Thus, cultural identity and space are closely related. Space is designed based on the existing cultural identity. An example of this combination is taverns. From the architecture, the decor, and the music to food and drink, taverns are "syncretic" spaces where the differences and reconciliation between the two communities in Cypriot culture are emphasized.

Taverns are generally the reflection of Cyprus's authentic rural life to our day. For this reason, characteristics of Cypriot rural life are found in their architecture. Arched doors and tools used in the past in rural life are preferred in the decoration of the space. In fact, the design of the space also represents the cultural design it's associated with. When it comes to culture of entertainment, music defines what we call the cultural ambiance, and the music in a space draws the boundaries of the cultural formation in that space, determining who can go there and who can't.

The descriptive references used in relation to Greek or Turkish quality of the cultural product (food, drink, music, dance) presented in the taverns determine the cultural attachment of the requesting customer according to the form of the request, and at the same time help to build coexistence, i.e. being an islander. The drinks, appetizers, and meals at the table are the cultural design of the table, while the requested and presented music is the cultural design of the music. Taverns are a space of cultural resolution that may include island culture. They have a lot of characteristics that can be associated with being an islander. Therefore, they have an important place in the island's culture of entertainment and they appeal to a wide audience. Taverns are spaces where the cultural elements of the two communities are offered separately or together, thus bringing about the differentiating or unifying nature of the cultural identities of the two communities.

The study looks at taverns selected from northern and southern regions of the island. When selecting taverns, the long history of service, presentation of live music and high popularity were taken into account. Thus, it was easier to examine the demands and tastes of the community, as well as whether there was a change in their service during the times when the gates, which help communication between two societies, were closed or open.

\section{Taverns as a Space of Cultural Reconciliation}

Turkish and Greek Cypriots have a similar food and drink culture. In the taverns on both sides of the island, the meals, appetizers, kebabs and desserts in the restaurants are no different. The authentic Cypriot songs performed in these places are also the same. The only difference is language and the instrument variation. The emphasis on nostalgic village life before the division of the island in the decorations of the taverns is important. This is also a sign of the fact that these two communities maintained their cultures during years of disconnection and their longing for the past. The presence of similar physical 
characteristics in the Turkish and Greek Cypriot taverns reveals that the two communities have a common understanding of tavern profile. With the opening of the gates and the resumption of communication between societies, people started to view the differences observed between the two communities as different colors within the whole rather than as discriminating points.

There are some habits that the two communities acquired from each other in the period they lived together before 1974. Even when the gates were closed and all kinds of exchange stopped, they tried to keep their habits as much as possible. The two communities maintained their culture, meals, and lifestyles in their new life spaces and constantly updated these habits. They found different solutions for the habits they could not bring with them. For example, drinks such as Anglia, Vsop Brandy, Zivania, and 31, produced in the southern part of the island and also enjoyed by Turkish Cypriots, reached the Turkish Cypriots in illegal ways during the 30-year period of disintegration or were available in taverns. The important point here is that Turkish Cypriots wanted to consume these drinks, which was part of a culture they adopted and were accustomed to, although they knew that it was illegal under the circumstances. This is a cultural request. Cultural behavior that people are accustomed to cannot be shaped by borders. Borders cannot decide what people will eat or drink, what music they will listen to, and what cultural behavior they will display.

As a result of the policies implemented after the war, there was an effort to regulate the behavior patterns that the Turkish Cypriots and the Greek Cypriots conducted or displayed together before the war in such a way that would lead to the polarization of the two societies. There were efforts to alienate two societies from each other by looking for differences. However, with the opening of the gates in 2003, many elements that were prohibited and described as taboo to a generation became reachable by the communities. Young people who were in communication with the other community for the first time found that the community, which had been described as very different from them is actually similar in many aspects and even demonstrates the same cultural behaviors. In this process, within all the organizations that aim at the convergence of the two societies, shared values were particularly emphasized and underlined.

While the taverns showed similarities in many aspects during the period of lack of communication between the two communities, the difference that some tried to expose in terms of repertoire and instruments was emphasized less in the two societies after the opening of the gates. Turkish and Greek Cypriots, who ceased communication during the period when the gates were closed, became even closer to the guarantor states of Turkey and Greece in cultural exchange as in many areas. For this reason, some differences emerged in daily cultural routines. The instruments and languages are symbols of the identities of societies and can cause a reaction from people. In this process, the two communities used the instruments of the guarantor states instead of using the instruments that were identified with each other and did not sing songs in each other's language. This has caused some differences in instrumentation. The Turkish musicians' performances in the Turkish side taverns included mostly violin, darbuka (cylindrical drum beaten with the hands), oud and clarinet, 
together with the identity-free instrument keyboard, which was added to this set after 1974 based on the influence of musicians coming from Turkey. On the other hand, the Greek Cypriots initially used violin, darbuka, lute and later added bouzouki, keyboard and sometimes accordion.

After the opening of the gates, the societies began to converge again. Today, Turkish and Greek Cypriot musicians work together in taverns, taking the stage with mixed repertoires and mixed instruments and perform music in Turkish and Greek languages. Currently, "We" and "Others", which are different expressions of today's shared repertoire, are rapidly being associated with "All of us". It is a common opinion that instruments are identified with the identities of societies. As a result, the bouzouki was previously perceived as a Greek instrument and was thus a divisive factor between the Turkish Cypriots and the Greek Cypriots. However, with the convergence of the two communities as a consequence of the changing politics of the island and the people's demand for an atmosphere of reconciliation, it started to have a unifying aspect. The joint programs by the Turkish and Greek musicians in taverns, the Turkish musicians singing songs in Greek and playing bouzouki and vice versa are all results of the existing demand. The owner of the place and the musicians, who take shape according to the expectations of the customers, also take the role of cultural mediators besides being shaped by the demand for the aim of making money. In these respects, although they differ from the bi-communal groups and orchestras, they essentially serve the purpose of enacting cultural reconciliation because the customers who prefer these places are those who support reconciliation between the two cultures. In this case, the stage emerges as a space where the problem is resolved.

\section{Musical Expression of Consolidation (Analysis)}

For the analysis, performance records recorded during observations in Turkish and Greek Taverns are taken as basis. The reason for this is to examine the relation between the symbols of the Cypriot culture, the taverns and musicians who hold an important place in this study. In the study, the verbal meaning, instrumentation, melody and performance were analyzed based on three popular songs entitled Dillirga- Tillyrkotissa, Feslikan- Psintri Vasilitzia Mou and Dolama/Na Su Goraso Mihanin, which are used by both communities in Cyprus and are associated with the common musical culture. As a result, it is possible to say that Turkish and Greek Cypriots have cultural partnerships in many respects. The same melodic structures, similar words, similar singing techniques and similar instrumentations confirm this. Cypriots did not abandon their cultural values and owned their habits that they identify with being a "Cypriot". However, in the post-1974 period, which was a barrier against the meeting of two cultures, the relations between the two communities on the island weakened and the people of the island underwent a process of convergence with the guarantor states. As a result, there were occasional differences in the languages in which the songs were performed and in the instruments they used 
to perform the songs. With the atmosphere of cultural reconciliation that desired to be established after the opening of the gates, the two communities began to use the new behaviors and elements they had acquired during the disengagement period to create a mixed music culture on the island.

Songs chosen are important parts of the island's music culture. These songs, which were originally Greek compositions but were called anonymous because the composer and the writer were unknown, were pieces used during the entertainment, celebration, and representation processes enjoyed by the two communities before the war period. After the loss of communication between the two communities during the post-war period, Turkish lyrics were written for Dillirga in 1982 and for Feslikan in 1985 by Cemal Özgürsel (Özgürsel 2008: Personal meeting). Thus, Turkish Cypriot musicians continued to perform these songs in Turkish. It has been observed that there are repetitions of bars originating from the difference of the two languages as well as differences in the size of the bar in the intros of the songs. In addition, due to the proximity to the guarantor countries, instruments like clarinet, bouzouki and keyboard were added to the main instrument sessions, which are violin, darbuka, oud and lute. However, with the opening of the border gates and with the merging effect created on the island, these changes, which seem to be differences in the beginning, started to be rearranged on the way to reconciliation. In these songs, divergences were seen as wealth rather than "we" and "others" and have been integrated with the concept of "all". In the versions where both languages were used, the Turkish lyrics were sang with extra repetition or Greek lyrics were cut short in order to eliminate the difference caused by the repetition of the bars. Thus, these songs became the area where reconciliation has been achieved, the musician became the reconciler and the taverns became the place in which this reconciliation process took place.

The context and attitude of music are shaped by the subjects for whome the societies care as well as those subjects' internalized values. As a result of my studies on the two communities and the above-mentioned songs, I find it possible to say the Greek Cypriots share the same attitude with the Turkish Cypriots toward not changing the lyrics-oriented and melodic core. Although Cypriots say that they are more open to change in music than in the lyrics, they demand that music is based on established patterns according to the place where it is used. There may be differences in instruments between the versions of a song played in a bar and in a tavern. The reason for this is the changing customer demand in line with space. At this point, the musician selects the songs according to the place where they will be performed and they are also shaped by the context with which they are associated. This context differentiates the manner of execution. The important issue here is that the musicians of the two communities demonstrate similar approaches to performing the same music in different places. They take care not to modify the core structure of the lyrics and the melody. As a result of these observations regarding the songs, it is possible to say that the island people display similar musical behavior. Behaviors toward reconciliation on the island do not signify the creation of a uniform identity. The emphasis here is the identity of the "Cypriot" that will be 
created by the Cypriot people who started living together and acting together. It is also natural that Turkish and Greek Cypriots are Turkish and Greek in their own right and occasionally demonstrate their own cultural behaviors.

\section{Musical Organizations in Cyprus toward Reconciliation}

After the island of Cyprus was divided into two in 1974, a new era started with the opening of the border gates in 2003. After years of efforts to alienate them from each other, the two communities, and particularly the young population, had the opportunity to observe their neighbors and their lives, with whom they had never communicated before. The resumption of inter-communal interaction triggered longing for change and peace between people. The dysfunctionality of the current situation and the emerging demand from the communities for resolution of the Cyprus problem also caused a change in the political conjuncture. These changes had a real impact on the island in a short time. The radios and televisions started to broadcast Greek songs that were previously taboo and banned directly by the government, and Turkish and Greek Cypriot artists began to cooperate in joint projects. Songs that were important for both communities started to be more frequently used. Along with changing ways of thinking, art, sports and business worlds, trade unions, NGOs and political parties started to form structures that carried out bi-communal works. These groups, working for peace, were built to unite the Turkish Cypriots and the Greek Cypriots living on the island, to enable them to get to know each other and to induce behaviors toward living together in both communities. In this section, the aspired atmosphere of reconciliation on the island is discussed based on "Bi-communal Chorus" that organized bi-communal events and the bi-communal folk dance company "Dance for Peace". The efforts of the Turkish and Greek Cypriots participating in these events to identify the island culture as a common culture and the effects of these on cultural identity were also examined.

"Encouraging cultural activities and creativity in conflict areas or areas affected by disasters will enable the affected communities to reconnect with their identities and regain a sense of normality, enjoying art and beginning to heal the scars of wars. Cultural programmes may also help foster appreciation of cultural diversity and paving the way towards mutual understanding" (Preis and Mustea 2013: 6).

\section{Bi-communal Chorus}

One of the most influential initiatives that enabled bi-communal events to be appreciated among the people and led the way for new ones is the "Bicommunal Chorus". The chorus started its activities in May 1997 before the opening of the gates and when ideas, such as shared homeland and common culture, were not voiced aloud. It became the largest and most effective organization that worked continuously and organized events. Chorus members 
are individuals from different age groups and professions, with the idea of unification of the island, who can read notes and who come together voluntarily by their own means. The chorus, which has one Turkish Cypriot, one Greek Cypriot conductor and volunteer members, carries out activities in support of peace and takes the stage in the events organized for this purpose. In the interview I did with the Greek Cypriot conductor of the chorus, Lena Melanidou, she defined the main objectives of the chorus as:

a. support two societies as they look out for each other and their culture and pass the common culture to the new generations,

b. be a role model for the idea of "common life in a common homeland" that will hopefully be a reality in the future through acknowledging differences and similarities and on the basis of mutual respect (Melanidou 2008, Personal meeting).

Considering the ideas that the chorus defends and wants to disseminate to the people, it can be observed that a comprehensive solution on the island and a common "Cypriot" culture are highlighted. The chorus members began their work at the Ledra Palace, which was under the management of the United Nations in the buffer zone in 1997 when the border gates were closed for transit and no cultural exchanges were possible. They expected no material compensation. However, due to the closed gates, the constant difficulties of getting permission for the meetings and the prohibitions, they had to continue their work in restaurants and private homes in the village of "Pile" where Turkish Cypriots and Greek Cypriots lived together. With the opening of the border gates, the work was carried back to Ledra Palace. The village of Pile, where the chorus worked during the time the gates were closed, is an important settlement where the Turkish Cypriots and Greek Cypriots lived together and the common life continued after the division on the island. Here, the borders separating the two communities were not able to divide the cultural unity, and the village hosted common culture spaces where a culture of reconciliation and Cypriotism were created. Thus, it is also a space where cultural solutions are produced. Turkish Cypriots and Greek Cypriots coming together in this village proved that borders could not prevent cultural communication and flow, which is also an assumption of this study. During the period when the chorus was founded, the challenges of working and the fact that no material compensation was expected are important points to consider. Due to these factors, they were able to be a reliable and long-term element in the issue of peace. In the number of participants, the management and decision-making mechanisms, the selection of the repertoire and the performance of the songs, the principle of equality has great importance. This is an effort by the chorus to become a successful role model for future unification. The chorus argues that the two communities on the island can continue to build together a common culture. For this reason, they are supported by the United Nations and political parties, trade chambers, nongovernmental organizations and people sharing the same ideas in the north and 
south of the island. The chorus has become an institution that is spiritually supported on the political ground. It presented a demand and acted for a resolution.

Figure 1. Rehearsal of Bi-communal Chorus in Pile (1999)

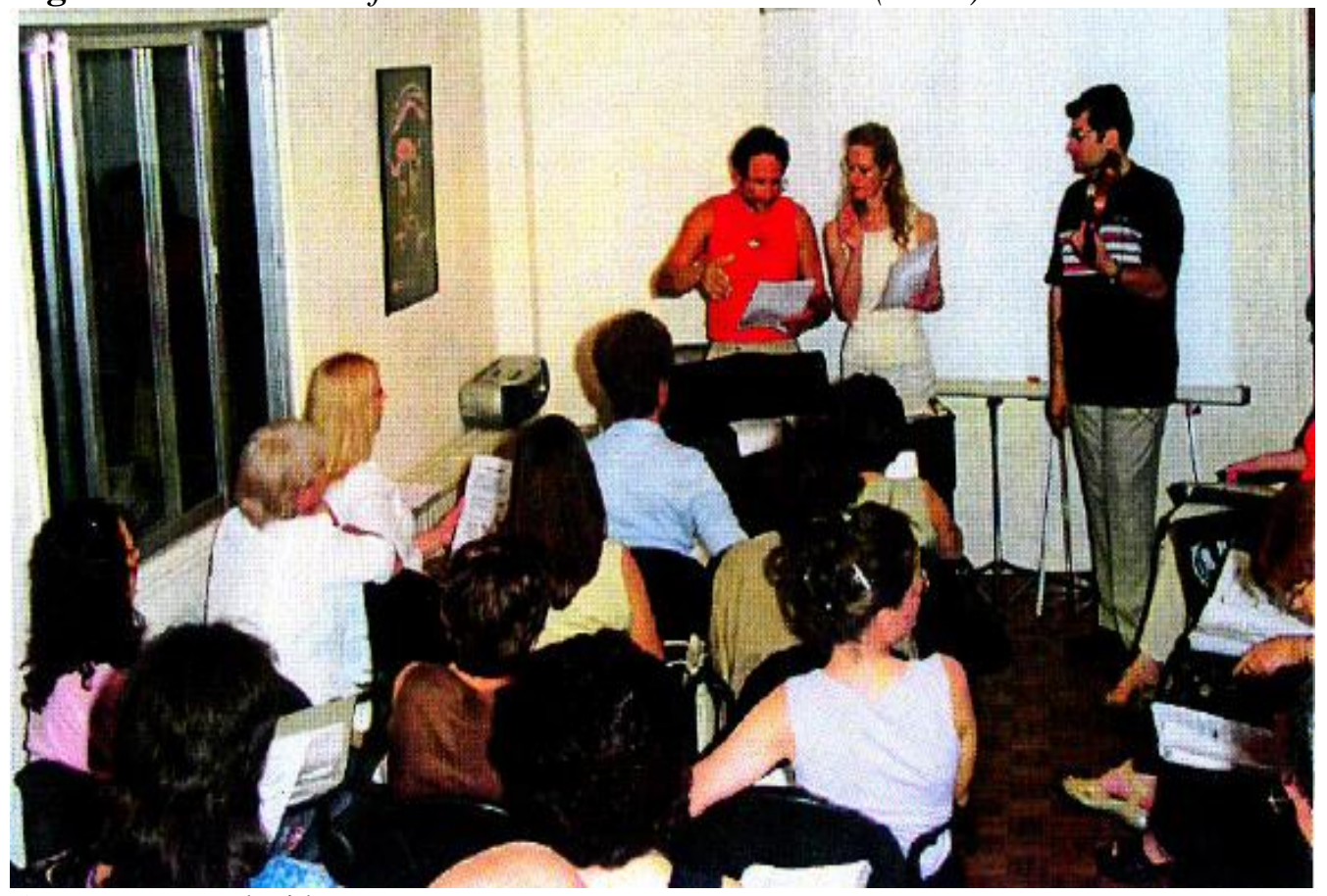

Source: Lena Melanidou

During the performance of the common repertoire, the Greek Cypriots singing Turkish and the Turkish Cypriots singing Greek lyrics is an example of the musical behavior being shaped to support the principal aim of the chorus. Furthermore, the pieces were performed in traditional forms with instruments such as violin, oud, lute, darbuka, and blended polyphonically with Western art and music such as piano, cello, flute, etc. to attract the attention of the world more easily. As a result, the Bi-communal Chorus, which had an influential place in social life, was supported by the internationally functional political ground, such as the United Nations and the European Union.

For the Bi-communal Chorus, the common culture formed by the Turkish and the Greek Cypriots when they lived together represents the reconciled area. Also, the fact that the chorus worked for the cultural unification even when there was no political unification effort on the island is an indication that the demand for reconciliation came from the people themselves. Today, the opening of the border gates, the existence of the political forces that are working for the resolution, the two communities being in communication again, and the foreign powers supporting the policies for reconciliation, significantly shape the demand for reconciliation that the chorus is trying to put forth. Cultural demands for reconciliation have now begun to come from both grassroots organizations and the administrations. 
Figure 2. Concerts of Bi-communal Chorus (February 2005-North Nicosia)

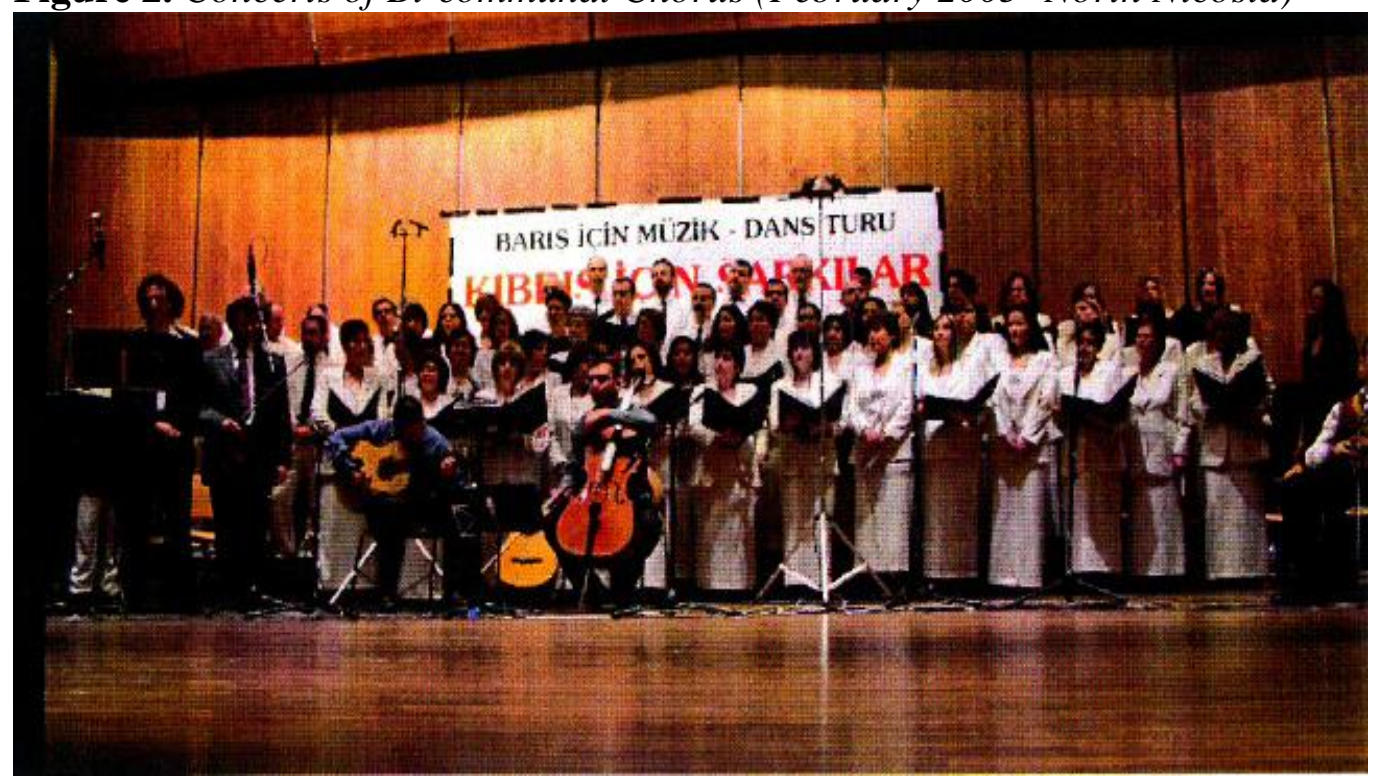

Source: Lena Melanidou.

\section{Dance for Peace}

The second example to be discussed among cultural reconciliation organizations is Dance For Peace, a bi-communal folk dance company composed of Turkish Cypriots and Greek Cypriots. The group was established in 2001 under the name "Steps For Peace" and was renamed as "Dance For Peace" in 2004. Chairman Mehmet Emin Eminoğlu states that the company was built in order to prove that the two communities in Cyprus can seamlessly live in a shared space without borders, using the common culture, by introducing common folklore to the new generations (Eminoğlu 2008, Personal meeting). Here, just like the bi-communal chorus, the administration and members are set in equal numbers for both communities and the system is based on equality. The troupe of 25 dancers of different ages and professions consists of individuals who believe in peace and voluntarily participate in efforts toward this purpose. The narratives and the musical behaviors that support it provide data regarding peace and reconciliation. Their joint activities and parallel work with the Bicommunal Chorus, which was formed for similar purposes, is an indication of the cooperation between organizations that serve the movements for reconciliation and peace. The group, which is a member of the World Dance Council (CID) and the Federation of World Folklore Festivals (CIOFF), is committed to participating in international shows and sharing their ideas on the reunification of Cyprus with the world. Their participation in events in the guarantor states and in the European Parliament in Brussels, which has an important role in the Cyprus issue, is an important step toward demonstrating cultural reconciliation in the political arena and finding support. The group has become well-known as a result of these initiatives and participates in activities organized by the EU Parliament and political ideologies seeking reconciliation. Today, it is an important advantage in terms of politics that the methods of solution and 
reconciliation, developed from the grassroots in bi-communal organizations, correspond to domestic and foreign political ideologies. Because bi-communal organizations that serve reconciliation have an important role in this process, they facilitate the acceptance of the political solution by both communities.

In this initiative, just as in the case of the Bi-communal Chorus, the organization takes great care so that every step, figure, music, costume, and behavior supports the unity of the two communities. By organizing bi-communal folklore seminars, they try to demonstrate with scientific data that Cyprus folklore is composed of common music, costumes, and figures. The aim is to own the common culture, and introduce it to the new generations as the Cypriot culture and to strengthen the ties among the communities. For this reason, they prefer using pieces and figures from both communities in their shows. Songs are performed in Turkish and Greek languages. Musicians are selected in equal numbers from both communities. The team is accompanied by an orchestra of violin, oud, lute, darbuka, tambourine, and accordion.

The fact that both Bi-communal Chorus and Dance For Peace adhere to the principle of equality when forming the repertoire, dances, membership, management, and other constructs, is a sign that the environment of reconciliation is created and implemented in the cultural space before the political space. Dance for Peace and the Bi-communal Chorus advocate a comprehensive solution on the island, underlining being "Cypriot" above the Turkish Cypriot and Greek Cypriot identities. They argue that the issues experienced on the island and the political developments that have taken place throughout history were planned and guided by the interests of foreign powers without the will of the Cypriots. They think that where these pressures do not exist, there is no obstacle against the unification of the Cypriots. Dance for Peace and Bi-communal Chorus are thus important cultural and musical behaviors toward unification.

Figure 3. Team of Steps for Peace 3 May 2003 - İn̈nü Square - North Nicosia

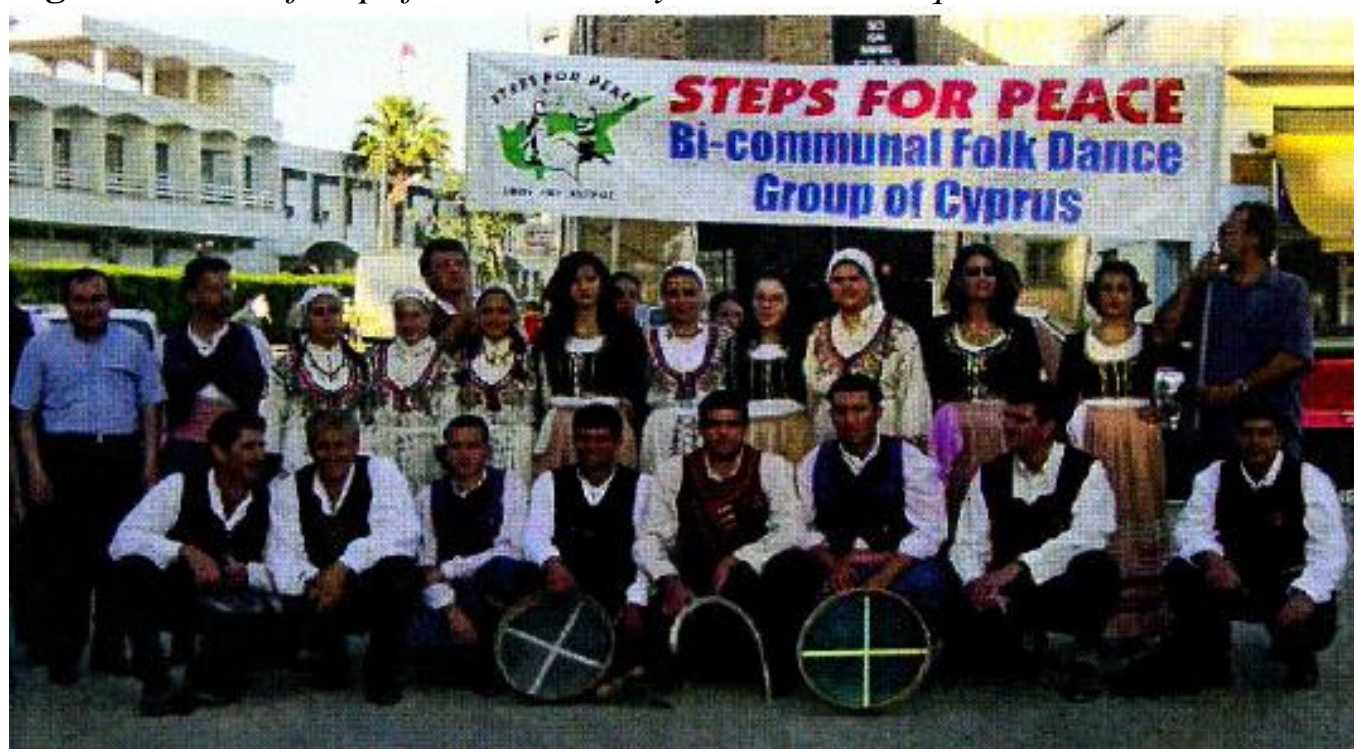

Source: Mehmet Emin Eminoğlu 


\section{Conclusion}

Music emerging as a means of self-expression is a power that people, and therefore communities, use to get to a point they want to reach. Through music, the desired messages are transmitted to large communities effectively and easily. It enables communication between communities and inspires action to resolve the existing problem. Music can bring people together in conflict, as well as in reconciliation. Even though it cannot shape the conflict or reconciliation by itself, it makes a significant contribution to the process by creating awareness. Music, one of the top means of communication and dialogue between communities, needs musicians to shape it according to a specified purpose because these musicians have responsibilities to the community to which they belong. Thus, they work for the resolution of the problems. The musician puts forth the demands of the community by using music according to its requests, expectations, and needs.

Thanks to the relation between cultural reconciliation and music, which also constitutes the title of this study, music has become one of the most important supporting factors for the communities to enter into reconciliation and peace processes by exhibiting musical dialogues toward reconciliation. The examples of the Bi-communal Chorus and Dance for Peace on the island of Cyprus reflected the demand of reconciliation arising from the people through music. This was an important step in creating that reconciliation. These groups were created in a period when bans were implemented and the communication between the two communities was cut off, and they showed the determination of the communities on the path of reconciliation. They used the stage as a place where the issue is resolved, and the music itself also emerged as the space of reconciliation. These communities confirm the assumption of the study that borders cannot completely prevent the convergence of cultures and cultural integrity. In these examples, Cypriots engaged in dialogue for reconciliation, using common cultural values to come together.

As a result of song analyses and observations in the taverns, which include important messages about the cultural identities of the two communities, it is possible to say that Turkish Cypriots and Greek Cypriots share a similar music and culture. Turkish Cypriots and Greek Cypriots did not abandon the cultural values they share or their habits they identified with being a "Cypriot" or "Islander." Therefore, they were able to retain the "Cypriot" identity during three decades of disintegration. The people of Cyprus taking shape around similar cultural values such as music, dance, food, and drink, use the values of Cyprus to create a common culture without debating their origins. The important fact here is that this culture belongs to Cypriots, and this represents the area of reconciliation. Music restored communication between the communities in Cyprus and enabled the young people to communicate and get closer to their neighborhood community. For this reason, music has produced beneficial results on the island of Cyprus as the main actor of reconciliation between communities and cultures. 
In recent years, a pursued goal on the island is to ensure that every part of the society cooperates with each other through support and cooperation programs that will bring the two communities closer, especially in cultural and social aspects. In addition to the governments of the two communities, many domestic and international institutions organize and provide funding for various activities and working environments to bring the two communities closer and increase their cooperation. Both communities support unity in arts, sports, business life, academic life and private life. For example, since 2009, the Stelios Bi-communal Awards have contributed "10,000" euros each year to 75 teams consisting of one Turkish Cypriot and one Greek Cypriot member. 75 teams selected by the Board can use this fund to implement their bi-communal projects they have developed in an area of their choice. Such supports increasingly encourage and boost the cooperation between Turkish Cypriots and Greek Cypriots. Thus, fusion, starting with small steps, broadens its area of influence in the society with an expanding circle. This is an indication of the public acceptance of these steps, which aim to bring the two communities closer together in order to ensure lasting peace on the island. The opportunities created for cooperation between the communities support the expansion of common areas of work each and every day. Intercultural communication, which started through culture in taverns and private homes in secret, has now begun to make itself evident in many aspects of life on the island. In particular, the areas of reconciliation created through the cultural elements of the island such as music, dance, and food now exist in larger areas.

\section{References}

Al-Taee N (2002) Voice of peace and the legacy of reconciliation: popular music, nationalism and the quest for peace in the middle east. Popular Music 21-1 (January): 41-61.

Asiliskender B (2004) Kimlik, mekan ve yer deneyimi [Identity, Space and Spatial Experience]. Kültür ve İletişim 7-2 (Summer): 73-94.

Bar-Siman-Tov Y (2004) Introduction: why reconciliation?. In Y Bar-Siman-Tov (ed) From Conflict Resolution to Reconciliation, 3-9. New York: Oxford University Press.

Bergh A, Sloboda J (2010) Music and art in conflict transformation: a review. Music and Arts in Action 2(2): 2-17.

Clark T (2004) Sanat ve Propaganda [Art and Propaganda], E. Hoşsucu, Trans. İstanbul: Ayrint1 Yayınları.

Cohen C (2015) Music: a universal language?. In O Urbain (ed) Music and Conflict Transformation: Harmonies and Dissonances in Geopolitics, 26-39. London, I.B. Tauris Publishers.

Edgar A, Sedgwick P (2007) Kültürel Kuramda Anahtar Kavramlar [Cultural Theory: The Key Concepts], M. Karaşahan, Trans. İstanbul: Açılım Kitap.

Eminoğlu ME, Head of Dance For Peace, Personal meeting. 10 April 2008, North Nicosia.

Erol A (2005) Popüler Müziği Anlamak: Kültürel Kimlik Băglamında Popüler Müzikte Anlam [Understanding Popular Music: Meaning in popular music in the context of cultural identity]. İstanbul: Bağlam Yayınları. 
García MEP (2014) Music and Reconciliation in Colombia: Opportunities and Limitations of Songs Composed by Victims. Music and Arts in Action. 4(2): 24-51.

Goodwin JA (2007) Breaking Down Barriers: Music and the Culture of Reconciliation in West Berlin 1961-1989. Doctoral Thesis, Department of History The College Art \& Science University of Rochester.

Gray AM (2015) Music as a tool of reconciliation in South Africa. In O Urbain (ed.), Music and Conflict Transformation: Harmonies and Dissonances in Geopolitics, 63-77. London: I.B.Tauris Publishers.

İyit K (2008) Popüler Müzik'te Marksist Söylem: Grup Munzur Örneği [Marxist Discourse in Popular Music: Group Munzur Example]. Unpublished Thesis, Dokuz Eylül University Musicology.

Kaemmer JE (1993) Music in Human Life, Anthropological Perspectives on Music, Y. Özer, Trans. (Unpublished), Austin: University of Texas Press.

Larrain J (1995) İdeoloji ve Kültürel Kimlik [Ideology and cultural identity]. NN Domaniç, Trans. İstanbul: Sarmal Yayınları.

Laurence F (2015) Music and empathy. In O Urbain (ed) Music and Conflict Transformation: Harmonies and Dissonances in Geopolitics, 13-25. London: I.B. Tauris Publishers.

Lipsitz G (1994) Dangerous Crossroads: Popular Music, Postmodernism and The Poetic of Place. New York: Verso.

Melanidou L, Conductor of Bi-communal Chorus, Personal meeting, 26 February 2008, South Nicosia.

Özgürsel C, Turkish lyrics writer of Dillirga and Feslikan, Personal meeting. 10 January 2008, Kyrenia.

Parekh B (2002) Çokkültürlülüğ̈̈ Yeniden Düşünmek Kültürel Çeşitlilik ve Siyasi Teori [Rethinking Multiculturalism: Cultural diversity and political theory]. B. Tanriseven, Trans. Ankara: Phoenix Yayınlar1.

Preis AB, Mustea CS (2013) Peace and reconciliation: how culture makes the difference, Unesco. (April.2013). Retrieved from http://bit.ly/2iAuQ59. Accessed September 2017.

Selçuk E (2016) Theodor Wiesengrund Adorno Ve Müzik Sosyolojisi [Theodor Wiesengrund Adorno and Music Sociology]. Unpublished Thesis, İstanbul Universty Faculty of Economics.

Stelios Philanthropic Foundation. Retrieved from http://bit.ly/2h7xR9D. Accessed September 2017. 
